\title{
AGILE GOVERNMENT DALAM MEWUJUDKAN BIROKRASI YANG BERKELAS DUNIA
}

\section{AGILE GOVERNMENT TO REALIZING A WORLD-CLASS BUREAUCRATIC}

\author{
Eka Putri Zulyani, Geovani Meiwanda \\ Program Studi Administrasi Publik, Universitas Riau, Indonesia \\ eka.putri2412@student.unri.ac.id, geovani.meiwanda@lecturer.unri.ac.id
}

\begin{abstract}
Abstrak
Birokrasi di Indonesia selalu di identikan dengan birokrasi yang bobrok. Pada mulanya Birokrasi muncul untuk dapat menciptakan persamaan persepsi antara pemerintah, masyarakat dan swasta. Birokrasi di cita-citakan menjadi jembatan penghubung dalam memberikan suatu pelayanan publik yang efektif dan efisien. Namun pada kenyataannya tidak sesuai yang diharapkan. Adanya penyakit birokrasi atau yang disebut dengan patologi birokrasi menjadi momok dalam menjalankan sistem pemerintahan. Korupsi, Kolusi, dan Nepotisme (KKN) menjadi wujud nyata bobroknya birokrasi Indonesia.Kerap kali permasalahan tersebut melibatkan Aparatur Negara (ASN) itu sendiri. Padahal tidankan tersebut telah menciderai keetisan seorang birokrat. Etika seorang birokrat sering sekali menjadi tolak ukur kepuasan masyarakat dalam menerima pelayanan. Maka dari itu, jika seorang birokrat melakukan tindakan yang menciderai etika seorang birokrat akan menmberi dampai tercideranya kepercayaan masyarakat terhadap pemerintah. Dikarenakan, birokrat adalah aktor yang memberikan pelayanan serta menjalankan sistem pemerintahan. Cita-cita Indonesia dalam mewujudkan pemerintahan yang bersih dari KKN sehingga dapat dikatakan sebagai pemerintahan yang berkelas dunia tentu saja tidak akan terwujud. Sistem pemerintahan yang berkelas dunia bergantung pada ASN atau aparatur yang berkelas dunia pula. Untuk itu, reformasi birokrasi hadir untuk dapat memperbaiki bobroknya birokrasi di Indonesia. Grand Design reformasi birokrasi 2012025 berfokus pada perbaikan kinerja seorang ASN atau aparatur negara. Dengan adanya reformasi birokrasi, diharapkan mampu mewujudkan pemerintahan atau birokrasi yang berkelas dunia.
\end{abstract}

Kata kunci: Birokrasi, ASN, Reformasi Birokrasi, Birokrasi berkelas dunia

\begin{abstract}
Bureaucracy in Indonesia is always identified with a dilapidated bureaucracy. At first the Bureaucracy emerged to be able to create a common perception between government, society and the private sector. Bureaucracy is aspired to be a connecting bridge in providing an effective and efficient public service. But in reality it is not as expected. The existence of bureaucratic disease or what is called bureaucratic pathology is a scourge in running the government system. Corruption, Collusion, and Nepotism (KKN) became a tangible manifestation of the dilapidation of the Indonesian bureaucracy. Many times the problem involved the State Apparatus (ASN) itself. Though the act has harmed the
\end{abstract}


ethics of a bureaucrat. The ethics of a bureaucrat is often a benchmark of community satisfaction in receiving services. Therefore, if a bureaucrat performs acts that injure the ethics of a bureaucrat, it will provide damage to the people's trust in the government. Because, bureaucrats are actors who provide services and run government systems. Indonesia's ideals in realizing a government that is clean from KKN so that it can be said to be a world-class government will certainly not be realized. World-class government system depends on ASN or world-class apparatus. For this reason, bureaucratic reform is here to improve bureaucratic collapse in Indonesia. Grand Design bureaucratic reform 201-2025 focuses on improving the performance of an ASN or state apparatus. With the bureaucratic reform, it is expected to be able to realize a world-class government or bureaucracy.

Keywords: Bureaucracy, ASN, Bureaucracy Reform, World-class bureaucracy

\section{Pendahuluan}

Etika sering sekali dipandang sebagai sesuatu yang kurang berkaitan dengan pelayanan publik. Padahal, etika merupakan salah satu elemen penting yang menentukan kepuasan publik dalam menerima pelayanan. Selain itu, etika dalam pelayanan publik diperlukan sebagai bentuk adanya sikap tanggap dari aparat birokrasi terhadap kepentingan masyarakat pengguna jasa. Dalam konteks ini, maka etika merujuk pada perilaku pemberi pelayanan yaitu Aparatur Sipil Negara (ASN) yang berperan sebagai aktor yang memberikan layanan. Dalam Undang - Undang Nomor 5 tahun 2014 tentang Aparatur Sipil Negara menyebutkan bahwa para aparatur sipil negara harus menjunjung tinggi standar etika yang luhur. Dalam Undang - Undang tersebut menjelaskan bahwa para pejabat publik harus memenuhi kode etik dan kode perilaku pegawai, diantaranya melaksanakan tugasnya dengan cermat dan disiplin, melayani dengan sikap hormat, sopan, dan tanpa tekanan, menjaga kerahasiaan yang menyangkut kebijakan negara.

Realitas menunjukan bahwa pemerintah tidak menerapkan kode etik kepegawaian secara memadai. Asumsi bahwa semua aparat pemerintah adalah pihak yang telah teruji pasti selalu membela kepentingan publik, tidak selamanya benar. (J,Idris, \& Burhanuddin, 2017). Data masih tingginya tingkat korupsi di Indonesia yang hampir semuanya melibatkan aparatur negara menunjukkan bahwa banyaknya aspek dalam birokrasi yang masih lemah (Supratman, 2018).

KKN merupakan salah satu bentuk dari adanya penyakit birokrasi atau yang lebih dikenal dengan patologi birokrasi. Hal ini dapat terjadi dikarenakan para penyelenggara negara tidak menyadari bahwa tindakan tersebut sangat tidak etis dan melanggar nilai moral seorang aparatur negara. Tindakan tersebut sangat tidak mencerminkan sikap profesionalitas seorang aparatur negara. Bagaimana Indonesia mampu mencapai pemerintahan yang berkelas dunia, sedangkan sistem penyelenggaraan pemerintahannya saja masih belum mencapai kata baik dengan dibuktikannya masih banyaknya kasus korupsi yang terjadi. Menurut data 
Transparancy International Indonesia (TII), Indeks Persepsi Korupsi (IPK) pada tahun 2015, skor Indonesia masih kalah dengan negara asia lainnya, seperti Singapura, Taiwan, Malaysia, Filipina, dan Thailand (Supratman, 2018).

Dalam mewujudkan birokrasi yang efektif, efisien, serta tanggap dan cekatan dengan birokrat yang profesional dan berintegritas dalam mewujudkan pemerintahan yang baik serta bersih dari KKN, maka diperlukannya Reformasi Birokrasi. Program Reformasi Birokrasi (RB) pada hakikatnya merupakan upaya untuk melakukan pembaharuan dan perubahan mendasar, terhadap sistem penyelenggaraan pemerintahan terutama menyangkut aspekaspek kelembagaan (organisasi), ketatalaksanaan (business process) dan Sumber Daya Manusia (SDM) aparatur.

Reformasi Birokrasi merupakan sebuah perubahan besar dalam paradigma dan tata kelola pemerintahan dengan penerapan prinsip clean government dan good governance dalam rangka memberikan pelayanan prima kepada masyarakat. Adapun Visi reformasi birokrasi adalah terwujudnya pemerintahan kelas dunia, yaitu pemerintahan yang profesional dan berintegritas tinggi yang mampu menyelenggarakan pelayanan prima kepada masyarakat dan manajemen pemerintahan yang demokratis, agar mampu menghadapi tantangan pada abad ke-21 melalui tata pemerintahan yang baik pada tahun 2025 (Hayat, 2017).

Untuk dapat mewujudkan birokrasi yang berkelas dunia, maka harus dimulai dengan aktor yang menyelenggarakan sistem pemerintah tersebut yaitu Aparatur Sipil Negara (ASN) yang berkelas dunia pula. Ada lima kriteria ASN yang berkelas dunia, yaitu profesional, integritas, orientasi kepublikan, budaya pelayanan yang tinggi, serta memiliki wawasan global. Dari kelima kriteria tersebut menunjukkan bagaimana seorang Aparatur Sipil Negara (ASN) harus bertindak atau berperilaku dalam memberikan suatu pelayanan. Karena pada dasarnya, kepuasan masyarakat atas pelayanan yang diberikan oleh pemerintah yang akan menjadi salah satu indikator dalam menjadikan suatu sistem penyelenggaraan pemerintah atau birokrasi yang berkelas dunia (Iriawan, Publik, \& Biak, 2019).

\section{Metode Penelitian}

Metode penelitian yang dilakukan oleh penulis ialah studi literatur dengan pendekatan kualitatif. Sedangkan data penelitian mengacu kepada hasil penelitian dari sejumlah literatur yang berkaitan. Data bersumber dari data sekunder dari buku, jurnal dan berita yang berkaitan dengan topik penelitian ini. 


\section{Pembahasan}

\section{Perilaku Aparatur Sipil Negara (Birokrat) di Indonesia}

Menurut Yahya Muhaimin Birokrasi adalah keseluruhan aparat pemerintah, baik sipil maupun militer yang bertugas membantu pemerintah (untuk memberikan pelayanan publik)dan menerima gaji dari pemerintah, oleh sebab itu peran birokrasi menjadi sangat strategis dalam rangka menyatukan persepsi dan perspektif antara negara dan masyarakat sehingga tidak terjadi kekacauan (Hartanto, Studi, Publik, Muhammadiyah, \& Utara, 2019). Pengertian birokrasi yang dikemukakan oleh hegel mengatakan bahwa birokrasi merupakan jembatan persepsi antara pemerintah dan masyarakat (Iriawan et al., 2019).

Menurut Sedarmayanti (2009:67) birokrasi merupakan sistem penyelenggaraan pemerintahan yang dijalankan oleh pegawai negeri berdasarkan peraturan perundangundangan. Pelaksanaan birokrasi identik dengan adanya pelayanan publik. Hal ini mengartikan bahwa Pegawai negeri ataupun Aparatur Sipil Negara (ASN) merupakan aktor yang memberikan pelayanan tersebut kepada masyarakat. Maka dari itu, bagaimana ASN itu bersikap serta berperilaku sangat menentukan jalannya birokrasi di Indonesia (Mongondow, 2019).

Namun kenyataanya, keberadaan birokrasi dalam pemerintah sering sekali dipandang secara dikotomis, selain dibutuhkan untuk melaksanakan urusan pemerntah sehari-hari, birokrasi juga dianggap sebagai sistem yang memyebabkan jalannya pemerintahan dan layanan publik tersendat dan bertele-tele. Cita-cita yang selalu didambakan oleh pemerintah Indonesia dalam mewujudkan birokrasi yang baik sampa sekarang hanya sebuah harapan. Terlihat bagaimana seorang Aparatur Sipil Negara yaitu ASN masih banyak yang tidak menyadari atas tanggung jawab yang telah dberikan kepada nya dalam menjalankan sistem pemerintahan, bahkan posisi tersebut digunakan sebagai alat dalam memuaskan keinginan probadi tanpa memikirkan kepentingan publik. Hal ini menunjukkan kurangnya profesionalisme serta rasa tanggung jawab yang dimiliki seorang Aparatur Sipil Negara.

Banyak kasus yang menunjukkan bobroknya birokrasi di Indonesia. Dari permasalahan Pungli (Pungutan Liar), pencaloan, hingga kasus Korupsi, Kolusi dan Nepotisme (KKN) yang merajalela. Seperti Kasus yang korupsi E-KTP dan Proyek Hambalang. Dalam konteks birokrasi, korupsi berkembang karena kuatnya demokrasi patrimonial yang menyamakan kekuasaan politik dengan kelembagaan birokrasi, dan lebih berorientasi pada pelayanan kepada penguasa atasan daripada kepentingan publik (Romli, n.d.).

Hal ini mencerminkan bahwa tidak profesionalnya yang dilakukan oleh seorang aparatur negara. Perilaku Aparatur Sipil Negara inilah yang menjadi salah satu pusat 
perhatian dalam memperbaiki birokrasi di Indonesia. Menjaga komitmen dalam menjalankan tugas atas kepentingan publik menjadi hal dasar seorang Aparatur Sipil Negara (ASN) menjalankan sistem pemerintahan di Indonesia (Nasir Djamil \& Massa Djafar, 2016). Dari banyaknya gejala penyakit birokrasi atau yang lebih dikenal dengan adanya patologi birokrasi, maka perlu adanya reformasi birokrasi untuk dapat memperbaiki serta mengoptimalkan penyelenggaraan sistem pemerintahan di Indonesia menuju pemerintahan yang berkelas dunia.

\section{Munculnya Reformasi Birokrasi Untuk Meningkatkan Profesionalisme Aparatur}

Sejarah birokrasi di Indonesia memiliki raport buruk, khususnya semasa Orde Baru hingga saat ini yang telah menjadikan birokrasi sebagai mesin politik. Tidak adanya kepastian waktu, biaya, dan siapa yang bertanggung jawab adalah beberapa fakta empiris rusaknya layanan birokrasi. Selain itu, layanan birokrasi justru menjadi salah satu causa prima terhadap maraknya korupsi, Kolusi, dan Nepotisme (KKN). Kondisi ini cukup lama terbangun sehingga membentuk sikap, perilaku, dan opini bahwa pejabat politik dan pejabat birokrat tidak dapat dibedakan. Dengan demikian birokrasi di Indonesia tidak berkembang menjadi lebih efisien. (Romli, n.d.)

Reformasi Birokrasi muncul untuk dapat memperbaiki permasalahan jalannya birokrasi di Indonesia. Sedarmayanti (2009:67) mengatakan bahwa reformasi ialah proses, upaya sistematis, terpadu, konferensif, ditujukan untuk merealisasikan tata pemerintahan yang baik. Sedangkan Prasojo (2009:15), mengatakan bahwa reformasi merujuk pada upaya yang dikehendaki, dalam suatu kerangka kerja yang jelas dan terarah, oleh karena itu persyaratan keberhasilan reformasi adalah eksistensi peta jalan (road map), menuju suatu kondisi, status dan tujuan yang ditetapkan sejak awal beserta indikator keberhasilannya (Iriawan et al., 2019). Indikator - indikator tersebut termaktub dalam Perpres nomor 81 tahun 2010 mengatakan bahwa reformasi birokrasi adalah upaya berkelanjutan yang setiap tahapannya memberikan perubahan dan perbaikan birokrasi kearah yang lebih baik seperti penyelenggaraan pemerintahan yang bersih dari Korupsi, Kolusi, dan Nepotisme (KKN), meningkatkan kualitas pelayanan publik yang prima disertai kapasitas dan akuntabilitas kinerja birokrasi, dan juga Profesionalisme SDM aparatur (Bersih et al., 2019)

Sehingga dapat disimpulkan bahwa reformasi merupakan sebuah upaya dalam menjadikan suatu pemerintahan yang lebih baik sesuai dengan keiinginan masyarakat. Dalam konteks ini, dalam mewujudkan pemerintahan yang baik maka fokus reformasi itu sendiri yaitu birokrasi. Sehingga reformasi birokrasi saat ini di.tujukan dalam memperbaiki kualitas Aparatur Sipil negara (ASN). Dikarenakan sistem penyelenggaran pemerintah yang baik salah satunya bergantung pada kualitas Aparatur Sipil Negara (ASN) (Birokrasi, 2018). 


\section{Reformasi Birokrasi Menuju Pemerintahan Yang Berkelas Dunia}

Istilah World Class (Berkelas Dunia) menurut Cambridge Dictionary diartikan sebagai seseorang atau sesuatu yang terbaik didalam jenis atau keloompoknya di dunia. Pengakuan terbaik ini merujuk pada penerapan standar yang berkualtas dalam hal rancangan, kinerja, kualitas, kepuasan pelanggan, dan nilai etika dibandingkan dengsn seluruh hal yang sama yang berasal dari manapun di dunia (Bussines Dictionary). Jika dikaitkan dengan sistem pemerintahan, maka suatu pemerintahan dapat dikatakan berkelas dunia ketika dapat mencapai standart tersebut.

Untuk dapat menjalankan sistem pemerintahan itu maka perlu adanya Aparatur negara. Oleh sebab itu, kinerja serta nilai etika yang diberikan oleh seorang aparatur negara menentukan kualitas sistem pemerintahan dan juga kepuasan masyarakat. Jika hal tersebut telah tercapai, maka pemerintahan tersebut dapat dikatakan sebagai pemerintahan yang berkelas dunia. Dapat disimpulkan bahwa dalam mewujudkan pemerintahan yang berkelas dunia maka perlu adanya Aparatur Sipil Negara yang berkelas dunia pula (ASN) (Hayat, 2017).

Birokrasi Indoneia sudah sering sekali diberi raport merah oleh masyarakat. Hal ini dikarenakan, wujud dari sistem pemerintahan tidak cepat tanggap akan kebutuhan masyarakat disertai dengan kurang profesionalnya seorang Aparatur Negara dalam memberkan pelayanan Publik. Seorang aktor yang menyelenggarakan sistem Pemerintahan atau yang lebih dikenal dengan Aparatur Sipil Negara (ASN) kerap kali mengabaikan nilai ataupun etika seorang birokrat. Seperti banyaknya kasus Korupsi, Kolusi, dan Nepotisme (KKN) yang dilakukan oleh seorang aparatur negara. Segala upaya telah diterapkan oleh pemerintah Indonesia seperti adanya penegakan hukum. Namun tetap saja permasalahan tersebut belum dapat diatasi. Sehingga birokrasi di Indonesia masih belum dapat dikatakan sebagai birokrasi yang berkelas dunia.

Perlu adanya kesadaran oleh seorang Aparatur Negara dalam mengatasi penyakit birokrasi tersebut. Maka Reformasi Birokrasi (RB) hadir untuk dapat memperbaiki sistem pemerntahan yang dapat dikatakan sebagai sistem pemerintahan yang bobrok (Bersih, 2012). Grand Design reformasi birokrasi 2010-2025 ditetapkan dengan Perpes No.81 Tahun 2010 merupakan langkah yang ditempuh untuk dapat melakukan percepatan pelaksanaan reformasi birokrasi itu sendiri. Kementrian PAN dan RB menetapkan sembilan program (langkah) percepatan birokrasi. Program yang dimaksud diantaranya (1) Penataan Struktur Birokrasi; (2) penataan jumlah dan distribusi PNS; (3) Sistem Seleksi CPNS dan Promosi PNS secara terbuka;(4) Profesionalis PNS; (5) Pengembangan Sistem Elektronik Pemerintah (E-Government); (6)Penyerdahanaan Perijinan Usaha; (7) Peningkatan Transparansi dan Akuntabilitas Aparatur; (8) Peningkatan Kesejahteraan Pegawai Negara; 
(9) Efisiensi Penggunaan Fasilitas, Sarana dan Prasarana Kerja PNS. Beberapa poin dari reformasi birokrasi tersebut berfokus pada aktor pemberi pelayanan yaitu Aparatur Sipil Negara (ASN) atau Pegawai Negeri Sipil (PNS).

Program tersebut dirancang untuk dapat meningkatkan kualitas seorang Aparatur Negara yang berintegritas dan profesional yang bersih dari KKN. Maka dari itu, jika ASN tersebut telah mencapai pada potensi yang profesional, hal ini akan berdampak pada pelaksanaan birokrasi yang baik pula. Sebagaimana yang telah dijelaskan oleh penulis sebelumnya bahwa Birokrasi berkeleas dunia akan tercapai apabila Aparatur negara Aatau ASN sebagai aktor yang memberikan layanan juga berstandarkan berkelas dunia.

\section{Penutup}

Birokrasi di Indonesia memang kerap kali dianggap sebagai pelayanan yang berteletele. Masyarakat kacap kali tidak merasa mendapatkan kepuasan atas pelayanan yang diberikan kepadanya sebagai konsumen. Aparatur negara yang seharusnya bertugas sebaga aktor yang memberikan pelayanan publik sepenuh hati dan mengutamakan kepentingan publik sering sekali terabaikan. ASN seolah melupakan tanggung jawab atas apa yang telah diberikan kepadanya sebagai penyelenggaran sistem pemerintah di Indonesia. Hal ini ditandai dengan maraknya penyakit birokrasi atau yang sering dikenal dengan Patologi Birokrasi yaitu KKN. Wujud pemerintahan bersih dari KKN yang di idam-idamkan hanya dianggap sebagai buah bibir oleh masyarakat. Apalagi kasus tersebut banyak tersangkut paut dengan keterlibatan ASN didalamnya yang menyebabkan adanya kurang kepercayaan masyarakat terhadap pemerintah. Perilaku tersebut sangat mencerminkan ketidak profesionalan ASN di Indonesia. Sehingga perlu adanya upaya perubahan dalam memperbaiki bobroknya birokrasi di Indonesia.

Maka dari itu reformasi birokrasi hadir dalam mengupayakan perbaikan atas bobroknya birokrasi di Indonesia. Selain itu, reformasi birokrasi juga hadir, dalam mengupayakan menjadikan birokrasi di Indonesia mencapai birokrasi birokrasi berkelas dunia. Untuk dapat mencapai birokrasi berkelas dunia, maka pengupayaan terpenting adalah memfokuskannya dalam memperbaiki kualitas pelayanan yang dilakukan oleh ASN. Dikarenakan, penyelenggaraan sistem pemerintahan yang profesional dan berkelas dunia ditentukan oleh kualitas ASN yang profesioanal dan berkelas dunia pula.

\section{Daftar Pustaka}

Hayat, H. (2017). Peneguhan Reformasi Birokrasi melalui Penilaian Kinerja Pelayanan Publik. Jurnal Ilmu Sosial Dan Ilmu Politik, 20(2), 175. https://doi.org/10.22146/jsp.248 
Iriawan, H., Publik, A., \& Biak, I. Y (2019). REFORMASI BIROKRASI DALAM PELAYANAN PUBLIK (Studi Kasus UPTB Samsat Kabupaten Biak Numfor ). 5, 128 141

J, S., Idris, M., \& Burhanuddin. (2017). Penerapan Etika Administrasi Negara Dalam Pelayanan Kenaikan Pangkat di Kantor Badan Kepegawaian dan Diklat Daerah Kabupaten Gowa. Jurnal Administrasi Publik, 3(1).

Nasir Djamil, M., \& Massa Djafar, T. (2016). Etika Publik Pejabat Negara dalam Penyelenggaraan Pemerintahan yang Bersih Ethics of Public Officials of the State in Operation Clean Government Operation Clean Government. Jurnal Kajian Politik Dan Masalah Pembangunan, 12(1), 1757-1768. 